\title{
The Strategy of the Environment and Hygiene Office in Overcoming the Existence of Illegal Temporary Shelter (TPS) in Pekanbaru
}

\author{
Nini Astuti ${ }^{1}$, Irawaty Irawaty ${ }^{2}$, Fara Merian Sari ${ }^{3}$ \\ 1,2,3 Department of Public Administration, Universitas Lancang Kuning, Indonesia \\ faramerian1988@gmail.com
}

\begin{abstract}
This paper discusses the strategies by Environment and Hygiene Office (DLHK) in overcoming the existence of illegal temporary shelter (TPS) in Pekanbaru. The theory used is the Hatten and Hatten which suggests what the principles in the success of a strategy are. While this is qualitative research with a descriptive design, the results show that Environment and Hygiene Office's strategy for combating the presence of illegal temporary shelter is adequate. However, due to the lack of public awareness to comply with the regulations set by the office, it was difficult for them to solve the problem of illegal temporary shelter in Pekanbaru.
\end{abstract}

Keywords: Strategy; public awareness; illegal temporary shelters

\section{Introduction}

Waste is the accumulation of solid items that are no longer usable as a result of the human activity remainder. Types of waste are divided into two, namely organic and inorganic waste. Organic waste is a readily biodegradable waste. Meanwhile, inorganic waste is a type of waste that is difficult to decompose.

The waste issue is currently crucial in Indonesia. The government executes various kinds of strategies in handling waste. From the standpoint of the government, they cannot handle the process of a policy to achieve its aim as a single actor (Yandra, Utami \& Husna, 2020). The government has collaborated with several parties to formulate a strategy for sustainably managing waste. For the solid waste sector, a waste processing site with a 3R (Reduce, Reuse, Recycle) pattern has been built or called TPS-3R.

The program is presumed to be a solution in waste management. However, in reality, the waste problem has not been fully resolved. One of the issues is the lack of public awareness not to litter, the government finds it challenging to deal with this problem.
Pekanbaru is the capital city of Riau Province, Indonesia. It is the most significant economical center in Sumatra, it is shown to have very high economic growth. Thus, the pace of economic growth and population in Pekanbaru will have implications for increasing waste production in the city area. With waste management that has not been following environmentally sound methods and techniques, it harms public health and the environment (Yandra \& Utami, 2018).

Based on the latest data from the Pekanbaru Environment and Hygiene Office, in December 2020, the waste products reached 1000 tons every day. This figure is relatively high compared to the Indragiri Hilir, which only gives 45 tons of waste per day. In addition, in waste management, adequate facilities and infrastructure are required in managing the waste produced by the citizens of Pekanbaru. One of these is called a Temporary Shelter or commonly abbreviated as TPS.

As attested by information from Environment and Hygiene Office (DLHK), on October 22, the number of illegal polling stations reached approximately 107 points spread throughout the district of Pekanbaru. 
In contrast, the official ones are only about 61 points. Consequently, the number of official temporary shelters available has not covered all the waste belonging to residents.

In conformity with the Section Head (Kasi) for Environmental Law Enforcement, Rubi Adrian, in an interview conducted by the researcher on December 8, 2020, said that ideally, the number of temporary shelters in an urban village is at least one while there are 83 urban villages in Pekanbaru. Moreover, the ideal number of official temporary shelter availability in Pekanbaru should have 83 points.

Meanwhile, the city only has 61 official polling stations. The availability is not sufficient enough. Thereupon the illegal temporary shelters have sprung up. The number of legal and illegal temporary shelters in 2015, 2016, and 2020 can be noticed from the following table:

\section{Table 1}

\section{The amount of legal and illegal polling} stations in 2015, 2016 and 2020

\begin{tabular}{|c|c|c|c|}
\hline No & Year & $\begin{array}{c}\text { Number of } \\
\text { legal } \\
\text { temporary } \\
\text { shelters } \\
\text { (TPS) }\end{array}$ & $\begin{array}{l}\text { Number of } \\
\text { illegal } \\
\text { temporary } \\
\text { shelters } \\
\text { (TPS) }\end{array}$ \\
\hline 1 & 2015 & 20 TPS & 100 TPS \\
\hline 2 & 2016 & 20 TPS & 98 TPS \\
\hline 3 & 2020 & 61 TPS & 107 TPS \\
\hline
\end{tabular}

Environment and Hygiene Office, December 2020.

As depicted by Table 1 , the number of illegal temporary shelters in 2020 has increased, which amounted to 107 points. The number of polling stations is quite large. Even the existence of illegal ones is straightforward to find along the streets. This issue, of course, will generate many problems. According to Surahma (2014), the impact of illegal temporary shelters is aesthetic problems such as unpleasant odors, eyesore, and discomfort. Besides, it can also disrupt the waters and pollute the environment.

This study aims to analyze the strategy of the Environment and Hygiene Office in surmounting the increasing number of illegal temporary shelters in Pekanbaru. With this research, it is expected that the researchers can fathom the parties' strategies in overcoming the problem of illegal temporary shelters in Pekanbaru.

\subsection{Concept Theory}

Executives must ensure that their strategies are thriving. For this reason, Hatten and Hatten (1988) in (Salusu, 2015:72-73) present some clues on how a strategy designed can be successful.

a. The strategy must be consistent with the environment. Do not make a strategy that goes against the flow. Keep up with the flow of developments in society in an environment that grants opportunities to move forward.

b. Every organization does not just create one strategy depending on the scope of its activities. If there are many strategies made, one strategy must be compatible with other strategies. Do not contradict. All strategies should be harmonized with one another.

c. An effective strategy should focus and combine all resources and not scatter them from one another. Unfair competition between various work units in an organization often claims its resources to separate it from other work units. Thus, that the unified forces harm its position.

d. The strategy should converge on what are its strengths and not on its weak points. In addition, it should also take advantage of competitors' weaknesses and take appropriate steps to occupy a stronger competitive position.

e. Resources are critical. Since strategy is possible, one has to come up with something feasible and workable.

f. The strategy should take into account the risk that is not too huge. Indeed, every strategy contains risks, but consideration must be taken not to plunge the organization into a big hole. Therefore, it should always be controlled.

g. Strategy should be adjusted grounded in the success that has been accomplished. 
Signs of the strategy's success are exhibited by the support from the relevant parties, especially from the executives and all heads of work units in the organization.

\section{Method}

This research was conducted at the Pekanbaru Environment and Hygiene Office, located at Jalan Datuk Setia Maharaja No. 04, Simpang Tiga, Bukit Raya District, Pekanbaru, Riau 28125.

Qualitative research with a descriptive design was employed as the basis for this research approach to answer the research questions. As specified by Saryono in Nurdin (2019: 75), qualitative research is used to investigate, find, describe, and explain the quality or privilege of social influences that cannot be explained, measured, or described through a quantitative approach.

The results of qualitative research are to understand the meaning, understand the uniqueness, construct phenomena and find hypotheses. It is also done due to the specifications of the research subjects and to obtain more profound information about the research studied.

The government's strategy in coping with illegal temporary shelters is a complex phenomenon that cannot be recognized only at the normative level and requires a research process to reveal the facts and meaning behind it. Accordingly, within Saryono's opinion regarding qualitative research, this research is entirely appropriate if one applies this method.

\section{Results and Discussion}

Strategy of the Environment and Hygiene Office in overcoming the presence of illegal temporary shelters in Pekanbaru.

\subsection{Strategy must be consistent with the environment.}

An effective plan must be compatible with its surroundings. Create no decisions that go against the flow. Keep up with the flow societal advancements in an atmosphere allows one to move forward.
In planning a strategy to subdue illegal temporary shelters, the Environment and Hygiene Office must plan a strategy consistent with the state of the environment. The strategy made by them so far has been very consistent with the state of the environment. This proof can be seen from the strategy invented by the Environment and Hygiene Office, adjusting to the state Pekanbaru population, which always raises annually.

In this case, the party is attempting to foresee the impact of Pekanbaru's growing population. The growing number of residents in Pekanbaru caused an expansion in the waste products. The Environment and Hygiene Office has anticipated this problem by forming a strategy appropriate to adjust to this situation.

\subsection{Every organization does not only form one strategy}

Every organization does not just make one strategy. It depends on the scope of its activities. If many strategies are provided, one of them must be coherent with the others. Contradictions should be avoided, and all strategies should complement one another.

The Environment and Hygiene Office employs more than one technique to prevent the presence of numerous unlawful temporary shelters in Pekanbaru. However, the party devised several methods to address this issue. Furthermore, all of these strategies are compatible with one another.

The strategies the Environment and Hygiene Office has carried out are as follows:

1. Land acquisition for legal temporary shelters construction

In 2018, the Environment and Hygiene Office submitted a compensation budget to the Pekanbaru Defense Services for the official land acquisition to construct temporary shelters in each urban village. However, in reality, many Pekanbaru residents refuse to have legal temporary shelters in their area as it smells foul, and so forth. The government's efforts Environment 
and Hygiene Office to obtain the legal ones have not been realized.

2. Conduct outreach to the community.

After failing to negotiate with the community for land acquisition, the Environment and Hygiene Office took steps to bring order to the community regarding waste disposal through socialization in October 2018-December 2018. It was performed by guiding the public regarding Pekanbaru City Regulation No. 8/2014 concerning Waste Management. The contents of the directive are:

a. The public is encouraged to dispose of waste only at the time determined by the Government, which is $19.00 \mathrm{WIB}-05.00$ WIB.

b. The public is prohibited from littering, such as on roads, parks, and bridges.

c. People are encouraged to provide trash cans in front of their homes or buildings and the cleaning staff can take out the trash in an orderly manner.

d. The public is urged to be disciplined in paying the garbage retribution so the garbage officers can maintain transporting the community's waste from the house-to-house.

Suppose the community is willing to comply with these regulations and be orderly in disposing of waste by the provisions set by the Pekanbaru City Government. In consequence, the problem of illegal temporary shelters can be solved quickly. Furthermore, the bare minimum of authorized temporary shelters may be adequate to cover all community waste in Pekanbaru.

\section{Forced sanctions}

After making an appeal and outreach to the community, however, there were no significant changes. On January 1, 2019, the Environment and Hygiene Office took firm action, namely the imposition of forced sanctions.

The strategic basis for the sanctioning action is Mayor Regulation Number 134 of 2018 concerning Procedures for Imposing Administrative Sanctions. The residents who are caught littering or throwing garbage outside the specified hours will be subject to OTT (Sting Operation) by the Environment and Hygiene Office Cleaning Task Force team.

Even though these regulations are in place, the number of residents who litter is still relatively large. It can be seen from the following table:

Table 2

The number of residents who were caught Sting Operation (OTT) for littering and outside the schedule for throwing garbage

\begin{tabular}{ccc}
\hline No. & Year & $\begin{array}{c}\text { The number of violators } \\
\text { caught sting operation. }\end{array}$ \\
\hline 1 & 2019 & 228 people \\
2 & 2020 & 316 people \\
& Total & 544 people \\
\hline
\end{tabular}

Source: Environment and Hygiene Office of Pekanbaru, 15 December 2020

Corresponding to the statistics, the overall number of residents who litter in Pekanbaru City is relatively high. In 2019, the first year of the enactment of Mayor Regulations of Pekanbaru No. 134/2018 concerning Procedures for Imposing Administrative Sanctions, the number of violators in the sting operation amounted to 228 people. Then in the following year, that number increased to 316 people. The number of people who litter this year has increased by 88 people. In conclusion, in the following table, it may be inferred that individuals continue to litter despite the fact that the Pekanbaru City Government has imposed a high amount of penalties. Therefore, a government strategy is needed to overcome these problems.

4. An effective strategy should focus and pool all resources

An efficient plan should concentrate and pool all resources rather than disperse them. The one-sided rivalry between multiple work units in an organization usually demands its resources, separating it from other work units and causing the combined forces to impair its position. 
Nini Astuti, Irawaty Irawaty, Fara Merian Sari / The Strategy of the Environment and Hygiene Office in

Overcoming the Existence of Illegal Temporary Shelter (TPS) in Pekanbaru

In dealing with the existence of illegal temporary shelters, the Environment and Hygiene Office realizes the need for synergy in the service. As a result, they have brought together all work units, particularly those responsible for resolving the issue of illegal temporary shelters.

\section{Resources are critical}

Since the strategy is possible, ones have to come up with something feasible and workable. Besides, the Environment and Hygiene Office has done so. It is evident from the community collaboration activities executed by their staff.

6. The strategy should take into account the risk that is not too large

Admittedly, every strategy contains risks, but consideration must be taken not to plunge the organization into a big hole. Therefore, a strategy should always be controlled. The Environment and Hygiene Office has taken into account the risks in making it. It can be viewed from the party's strategy, which is reluctant to transport waste beyond the capacity of the garbage truck, and it might there is no damage to the fleet. The waste might be unserved in an area because the fleet is responsible for the area being damaged.

The Environment and Hygiene Office carries out control activities for each strategy implemented as well. Moreover, on every ongoing regulation, supervision is constantly done by the Environmental and Hygiene Office. With these monitoring activities, the party can determine the advantages and disadvantages of this strategy.

7. Strategy should be formulated based on the success that has been achieved

Do not strategize on failure. The Environment and Hygiene Office consistently aims for strategies derived from previous success when developing a strategy to solve the problem of illegal temporary shelters in Pekanbaru. They continuously evaluate the programs that have been implemented. Thereupon in the future, the party can compose an even better strategy.

\section{Signs of a successful strategy}

The support of the necessary parties, particularly the executives and the heads of work units in the company, is evidence of the strategy's effectiveness. In dealing with illegal temporary shelters, the Environment and Hygiene Office has received support from the Mayor of Pekanbaru.

\section{Conclusion}

The researchers draw the following conclusions from this research on the Strategy of the Environment and Hygiene Office in combating the existence of illegal temporary shelters in Pekanbaru:

1. The strategy implemented by the Environment and Hygiene Office has been excellent, but the strategy has not been implemented optimally owing to the absence of public awareness to participate in maintaining environmental cleanliness.

2. The inhibiting factors for the Environment and Hygiene Office in overcoming the presence of illegal temporary shelters in Pekanbaru are:

a. External factors

1) The habit of citizens who like littering carelessly

2) It is difficult to change people's mindset

3) There are interested parties

4) The community does not comply with the regulations that the government has set.

b. Internal factors

1) Less operational costs

2) Lack of Human Resources

\section{References}

Congge, U., \& Sos, S. (2017). Patologi Administrasi Negara (Vol. 1). SAH MEDIA.

Kambuaya, B. Menembus Badai KEPEMIMPINAN (Vol. 1). SAH MEDIA.

Kurniati, Y. Strategi Dinas Lingkungan Hidup Terhadap Pencapaian Pemungutan Retribusi Pelayanan 
Persampahan/Kebersihan Di Kota Batam Tahun 2017. Strategi Dinas Lingkungan Hidup Terhadap Pencapaian Pemungutan Retribusi Pelayanan

Persampahan/Kebersihan Di Kota Batam Tahun 2017.

Mulasari, S. A. (2014). Keberadaan TPS legal dan TPS ilegal di kecamatan godean kabupaten sleman. KEMAS: Jurnal Kesehatan Masyarakat, 9(2), 122-130.

Novianto, E. (2019). Manajemen Strategis. Deepublish.

Nurdin, I., \& Hartati, S. (2019). Metodologi penelitian sosial. Media Sahabat Cendekia.

Ode, H. (2019). Pengembangan Organisasi Berbasis Spiritual. Jakad Media Publishing.
Pasolong, H. (2014). Teori administrasi publik.

Purhayani, A. S. (2019). Strategi Dinas Lingkungan Hidup Dalam Menanggulangi Sampah (Studi Dinas Lingkungan Hidup Kota Bandar lampung) (Doctoral dissertation, UIN Raden Intan Lampung).

Yandra, A., \& Utami, B. C. (2018). Anomaly Kepentingan Elit Dalam Kebijakan Public Privat Partnership (PPP) di Kota Pekanbaru. Jurnal Niara, 11(2), 142-149.

Yandra, A., Utami, B. C., \& Husna, K. (2020). Distortion of Government Policy Orientation in Public-Private Partnership (PPP). Policy \& Governance Review, 4(1), 40-54. 